\title{
Krwawy świt, m roczny dzień... Problemy Rzeczypospolitej początku XVII wieku w świetle literatury okolicznościowej
}

Jacek Wójcicki 
XAP7S Seria XII 2006

\section{Krwawy świt, mroczny dzień... \\ Problemy Rzeczypospolitej początku XVII wieku w świetle literatury okolicznościowej}

$\mathrm{D}$ wunasta seria „Napisu” zawiera materiaty konferencji naukowej pod powyzszyn hastem, która odbyla się od 11 do 13 października 20)16 roku w Sandomierzu - mieście malowniczo wznoszącym się 11a skarpie nad Wislą, niezwykle ważnym dla tytulowych wydarzeń, ponieważ tam właśnie przed czterystu laty skrystalizowal się organizacyjnie ruch zbrojnej opozycji szlacheckiej. Od nazwiska jednego z najaktywniejszych przywódców ruch ten znany jest też jako rokosz Zebrzydowskiego, wojewody krakowskiego, kontrastowo zapisanego w naszych dzicjach takze jako fundator instytucji skierowanej ku metafizyce i odwiecznemu ladowi — stynnej pielgrzymkowej Kalwarii na wzgórzach pod Lanckoroną.

Wielorako odzwierciedlone w literaturze okolicznościowej zagadnienia polityki wewnętrzncj tamteggo okresu. którego tragiczna kulminacja nastąpiła na polı bratobójczej bitwy pod Guzowem w lipcu 1607 roku, stały się tematem obrad sekcji „polskiej”, ogarniającej tez zagadnienia retoryki i socjotechniki, mobilizowanej w .pospolitym ruszeniu" wieku wojen. Równolegle procedowata sekcja „moskiewski”, gdzie dominantą przedstawionych wystapieri bylo zaangazowanie się Rzeczypospolitej w ..wielki zamęt" u sąsiada o wiele potężniejszego, niz z początku sądzono, gdy dawano temu wyraz w optymistycznej publicystyce i poezji - na ziemiach Wielkiego Księstwa Moskiewskiego. Tematem referatów i żywej dyskusji były więc barwne i bujne awantury obu Dymitriad, smoleńska i moskicwska epopeja Polaków, wojenne wyprawy Wazów i ich konsckwencje, widziane w perspektywie zarówno rodzimej, jak i obcej, nie tylko na ówczesnym theatrmm wojny. lecz takze z dystansu nawet dwudziestowieczneggo. A skoro o Wazach nowa dodać należy, że konferencje zamknęty referaty zebrane w stworzonej ad hoc sekcji ,.szwed zkicj” — niewiclkicj rozmiarami, lecz obszernej przez zakres chronologiczny: od początku do połowy wieku, od sporów o Inflanty aż do czasów „potopu”.

Serdecznej gościny tegorocznym obradom udzieliła Wyższa Szkoła I Iumanistyczno-Przyrodnicza - Studium Generale Sandomiriense, która poprzez uczynne starania Dziekan 
4 Krwawy świt. mroczny dzicin... Problemy Rzeczypospolitcj początkı XVII wicku...

Wydziału Humanistycznego, dr Doroty Sarzyńskiej, oraz dra Grzegorza Trościńskiego z Zakladu Filologii Polskiej tegoż Studium zadbała o dach, wikt i kulturalıą uciechę dla gości z różnych ośrodków naukowych kraju. Pod fachowym przewodnictwem mgr Aleksandry Malarz chętni referenci i goście zwied zili bajeczny Sandomierz, wędrując jego wąwozami i wzgórzami, zaglądając do gotyckich świątyń, radując siẹ micjskimi i zamiejskimi pejzażami.

Zanim jednak to nastąpilo, uczestnicy wziç li aktywny udzial w konferencji, nad którą patronat objął Burmistrz Miasta Sandomicrza mgr inz. Jerzy Borowski. Obrady otworzył prof. dr hab. Antoni Gawron, Prorektor WSI IP-SGS, której kadra i studenci wyrazili zainteresowanie konferencją. W imieniu Burmistrza do zebranych przemówił jego I Zastępca, mgr Krzysztof Krzystanek, a w imieniu Towarzystwa Naukowego Sandomierskicgo dr Jan I lajduk, kierownik Sekcji I Iumanistycznej. Patronat medialny nad konferencją objęlo Radio Kielce.

Wspólorganizatorami spotkania były tradycyjnie: Pracownia Literatury Okolicznościowej i Użytkowcj Instytutu Filologii Polskiej Uniwersytetu Warszawskiego oraz Zespół Badań Obszarów Trzecich Literatury, afiliowany przy Instytucie Badań Literackich Polskiej Akademii Nank. Materiały tekstowe, uporządkowane zasadniczo wedle clnronologii, uzupetniono o wystapienia osób z różnych powodów nieobecnych na konterencji oraz o artykuly spoza głównego nurtu tematycznego obecnej serii.

Teraz dni u nas są znacznic pogodniejszć; zapraszany do spokojnej lektury! 